\title{
Milk Fat Responses to a Change in Diet Fermentability Vary by Production Level in Dairy Cattle ${ }^{1,2}$
}

\author{
B. J. Bradford and M. S. Allen \\ Department of Animal Science, \\ Michigan State University, East Lansing 48824
}

\begin{abstract}
The effects of dietary starch fermentability on plasma metabolites and hormones, milk production, and milk fatty acid profile were evaluated in a crossover study. Thirty-two multiparous Holstein cows $(121 \pm 48 \mathrm{~d}$ in milk, $41 \pm 9 \mathrm{~kg} / \mathrm{d} 3.5 \%$ fat-corrected milk [FCM]; mean $\pm \mathrm{SD}$ ) were randomly assigned to treatment sequence and were fed a diet intermediate to the treatments during an initial 21-d period. Treatments were dry ground corn grain (DG) and high moisture corn (HM) harvested from the same field. Treatment periods were $14 \mathrm{~d}$, with the final $4 \mathrm{~d}$ used for data and sample collection. Diets included corn silage and alfalfa haylage at a 2:1 ratio and were $\sim 26 \%$ neutral detergent fiber, $16.5 \%$ crude protein, $32 \%$ starch, and $3.5 \%$ fatty acids. High moisture corn increased plasma glucose, nonesterified fatty acid, and triglyceride concentrations, but treatment had no consistent effect on yield of milk or FCM. High moisture corn increased trans $\mathrm{C}_{18: 1}$ concentrations at an increasing rate as production level decreased across cows, and milk fat depression was evident in cows below approximately $40 \mathrm{~kg} / \mathrm{d}$ FCM yield. In contrast, production level had little influence on milk trans $\mathrm{C}_{18: 1}$ concentration for DG. Milk trans $\mathrm{C}_{18: 1}$ concentration was negatively correlated with milk fat concentration, as was trans $-9 \mathrm{C}_{18: 1}$, trans- $10 \mathrm{C}_{18: 1}$, and cis- 9 , trans$11 \mathrm{C}_{18: 2}$. Concentration of trans-10, cis-12 $\mathrm{C}_{18: 2}$ was not correlated with milk fat concentration. Production level may influence biohydrogenation patterns and trans $\mathrm{C}_{18: 1}$ production because of differences in rumen environment; rumen $\mathrm{pH}$ and dilution rate can alter metabolism and populations of rumen microbes. Diets with
\end{abstract}

\footnotetext{
Received June 24, 2004.

Accepted July 20, 2004.

Corresponding author: M. S. Allen; e-mail: allenm@msu.edu.

${ }^{1}$ Presented in part at the American Dairy Science Association Annual Meeting, July 2004, St. Louis, MO [B. J. Bradford and M. S. Allen (2004) "Increasing dietary starch fermentability causes milk fat depression in low-producing, but not high-producing cows." J. Dairy Sci. 87 (Suppl. 1): 308(Abs.)].

${ }^{2}$ This material is based upon work supported by the Cooperative State Research, Education, and Extension Service, U.S. Department of Agriculture, under Agreement No. 2004-35206-14167, and under a National Science Foundation Graduate Research Fellowship.
}

highly fermentable starch sources and without supplemental dietary polyunsaturated fatty acids can induce milk fat depression in lower-producing cows, likely because of increased production of trans $\mathrm{C}_{18: 1}$ fatty acids. (Key words: milk fat depression, starch fermentability, trans fatty acid, dairy cow)

Abbreviation key: $\mathbf{D G}=$ dry ground corn grain, $\mathbf{H M}=$ high moisture corn grain, MFD = milk fat depression .

\section{INTRODUCTION}

High-producing dairy cows require high concentrations of dietary energy to meet requirements for maintenance, milk synthesis, and reproduction. In the United States, these energy requirements are often met by adding corn grain to the diet. While corn grain, in general, is a highly digestible energy source, its ruminal fermentability may vary greatly due to differences in preservation method. Studies have shown increases in ruminal starch digestibility of roughly $20 \%$ for high moisture corn diets (HM) relative to ground dry corn diets (DG) (Knowlton et al., 1998; Oba and Allen, 2003b). These large differences in starch digestibility alter the rumen environment and the profile and temporal patterns of nutrients absorbed, potentially affecting DMI, nutrient partitioning, and milk yield.

For years, dairy rations that included relatively high concentrations of starch have been correlated with the condition known as milk fat depression (MFD). Decreased ruminal $\mathrm{pH}$ is generally assumed to be the ultimate cause of this phenomenon in low-fiber diets (Bauman and Griinari, 2003). However, increased starch fermentability in a high-starch diet caused a $15 \%$ depression in milk fat yield without any treatment differences in mean or variance of ruminal $\mathrm{pH}$ in a recent study (Oba and Allen, 2003a). Surprisingly, DMI responses in that study ranged from +2 to $-4 \mathrm{~kg} / \mathrm{d}$ when HM was substituted for DG (unpublished data). The large variation between cows in response to starch fermentability suggests that treatment means may not be sufficient for determining the mechanisms driving DMI or MFD in this situation.

Interactions between production level and diet are rarely discussed in the literature despite the broad con- 
sensus that cows of different production levels should be fed differently. High-producing cows absorb and use nutrients at a faster rate than less productive cows, and because the liver and rumen are important sites for control of DMI and nutrient partitioning (Allen, 2000), production level is an important factor to consider in metabolic studies. The objective of this experiment was to determine if intake and production responses to a change in diet fermentability are related to production level.

\section{MATERIALS AND METHODS}

Experimental procedures were approved by the AllUniversity Committee on Animal Use and Care at Michigan State University.

\section{Design and Treatments}

Thirty-two multiparous Holstein cows (121 448 DIM; mean \pm SD) from the Michigan State University Dairy Cattle Teaching and Research Center were assigned randomly to sequence in a crossover experiment balanced for carryover effects. At the beginning of the experiment, body weight of cows was $675 \pm 69 \mathrm{~kg}$, and $3.5 \% \mathrm{FCM}$ yield was $41.3 \pm 9.6 \mathrm{~kg} / \mathrm{d}$ (mean $\pm \mathrm{SD}$ ). One cow was removed from the experiment prior to its completion because of mastitis. Prior to the initial treatment period, all cows were fed a single diet intermediate in composition to the 2 treatment diets for $21 \mathrm{~d}$. The purpose of this preliminary period was to obtain baseline values for DMI and milk yield and to conduct glucose and propionate challenge tests independent of dietary treatments. Results of the challenge tests will be reported elsewhere.

Treatments were conservation method of corn grain (HM vs. DG). One corn hybrid (Great Lakes 4526; Great Lakes Hybrids, Ovid, MI) was grown in 2002, and onehalf of the field was harvested at a DM concentration of $69.1 \%$. Corn was ground and ensiled as HM treatment in a 2.4- $\times 30.0-\mathrm{m}$ silage bag (Ag Bagger; Ag Bag Corp., Blair, NE). The remaining one-half of the field was harvested as DG at $83 \% \mathrm{DM}$, dried to $86 \% \mathrm{DM}$, and finely ground. Experimental diets contained either HM or DG, corn silage, alfalfa silage, a premix of protein supplements (soybean meal, blood meal, and SoyPlus [West Central Soy, Ralston, IA]), a premix of minerals and vitamins, and a liquid urea/molasses supplement (Quality Liquid Feeds, Dodgeville, WI). All diets were formulated for $18 \%$ dietary CP concentration and fed as TMR. Nutrient composition of experimental diets is shown in Table 1. Treatment diets did not include supplemental fat, and fatty acid profiles of the diets were very similar (Table 2 ).
Table 1. Ingredients and nutrient composition of experimental diets. ${ }^{1}$

\begin{tabular}{|c|c|c|c|}
\hline Item & $\mathrm{P}$ & DG & $\mathrm{HM}$ \\
\hline \multicolumn{4}{|l|}{ Diet ingredient } \\
\hline Dry ground corn grain & 14.7 & 30.3 & - \\
\hline High moisture corn grain & 15.8 & - & 32.1 \\
\hline Alfalfa haylage & 15.4 & 14.9 & 14.5 \\
\hline Corn silage & 30.7 & 30.8 & 30.0 \\
\hline Protein mix $^{2}$ & 15.2 & 15.6 & 15.2 \\
\hline Mineral and vitamin $\operatorname{mix}^{3}$ & 5.3 & 5.4 & 5.3 \\
\hline Liquid urea/molasses supplement ${ }^{4}$ & 2.9 & 3.0 & 2.9 \\
\hline \multicolumn{4}{|l|}{ Nutrient composition } \\
\hline DM & 46.1 & 49.1 & 47.8 \\
\hline OM & 93.3 & 93.5 & 93.6 \\
\hline Starch & 31.5 & 31.7 & 32.8 \\
\hline NDF & 25.1 & 26.2 & 25.3 \\
\hline Indigestible $\mathrm{NDF}^{5}$ & 7.0 & 6.8 & 6.7 \\
\hline $\mathrm{CP}$ & 15.3 & 16.5 & 16.3 \\
\hline Fatty acids ${ }^{6}$ & & 3.4 & 3.5 \\
\hline
\end{tabular}

${ }^{1} \mathrm{P}=$ Preliminary period diet, $\mathrm{DG}=$ dry ground corn diet, and $\mathrm{HM}=$ high moisture corn diet. Values other than DM are expressed as a percentage of dietary DM.

${ }^{2}$ Protein mix contained $75 \%$ soybean meal, $20 \%$ bloodmeal, and $5 \%$ SoyPlus (West Central Soy, Ralston, IA) on a DM basis.

${ }^{3}$ Mineral and vitamin mix contained 58.5\% DG, $17.0 \%$ limestone, $10.5 \%$ dicalcium phosphate, $7.9 \%$ sodium bicarbonate, $2.1 \%$ magnesium oxide, $1.7 \%$ trace mineral premix, $1.6 \%$ trace mineral salt, and $0.8 \%$ vitamin $\mathrm{A}, \mathrm{D}$, and $\mathrm{E}$ premix.

${ }^{4} \mathrm{QLF}$ Dairy TMR 20.

${ }^{5}$ Estimated after $120 \mathrm{~h}$ of in vitro ruminal fermentation.

${ }^{6} \mathrm{P}$ not analyzed.

\section{Data and Sample Collection}

Throughout the experiment, cows were housed in tie stalls and fed once daily ( $1000 \mathrm{~h})$ at $115 \%$ of expected intake. Treatment periods were $14 \mathrm{~d}$, with the final $4 \mathrm{~d}$ used to collect samples and data. Samples of all dietary ingredients $(0.5 \mathrm{~kg})$ were collected daily and composited into one sample per period. Cows were milked twice daily in a milking parlor, and milk was sampled and yield recorded at every milking on d 11 to 14 of each period. Blood samples were collected every $9 \mathrm{~h}$ during d 12 to 14 of each period to represent every $3 \mathrm{~h}$ of a 24$\mathrm{h}$ period. Blood was sampled from coccygeal vessels and collected into 2 evacuated tubes, one containing potassium EDTA and the other containing potassium oxalate with sodium fluoride as a glycolytic inhibitor.

Table 2. Fatty acid profile of treatment diets.

\begin{tabular}{lrr}
\hline Fatty acid $(\mathrm{g} / 100 \mathrm{~g})$ & $\mathrm{DG}^{1}$ & $\mathrm{HM}^{2}$ \\
\hline $16: 0$ & 13.7 & 13.7 \\
$18: 0$ & 2.3 & 2.2 \\
$18: 1$, cis-9 & 14.4 & 14.7 \\
$18: 2$, cis-9, cis-12 & 38.0 & 38.0 \\
$18: 3$, cis-9, cis-12, cis-15 & 7.8 & 7.6 \\
\hline
\end{tabular}

${ }^{1} \mathrm{DG}=$ Dry ground corn diet.

${ }^{2} \mathrm{HM}=$ High moisture corn diet. 
Both were centrifuged at $2000 \times g$ for 15 min immediately after sample collection, and plasma was harvested and frozen at $-20^{\circ} \mathrm{C}$ until analysis. One plasma sample from each tube containing $\mathrm{K}_{3}$ EDTA was preserved with benzamidine ( $0.05 \mathrm{M}$ final concentration), a proteolytic inhibitor that prevents glucagon degradation (Ensinck et al., 1972; Matsunaga et al., 1997).

\section{Sample and Statistical Analysis}

Diet ingredients were dried in a $55^{\circ} \mathrm{C}$ forced-air oven for $72 \mathrm{~h}$ and analyzed for DM concentration. All samples were ground with a Wiley mill (1-mm screen; Arthur H. Thomas, Philadelphia, PA). Ash concentration was determined after $5 \mathrm{~h}$ of oxidation at $500^{\circ} \mathrm{C}$ in a muffle furnace. Concentrations of NDF were determined (Van Soest et al., 1991; method A), and CP was analyzed according to Hach et al. (1987). Starch was measured by an enzymatic method (Karkalas, 1985) after samples were gelatinized with sodium hydroxide; glucose concentration was measured with a glucose oxidase method (Glucose kit \#510; Sigma Chemical Co., St. Louis, MO), and absorbance was determined with a microplate reader (SpectraMax 190; Molecular Devices Corp., Sunnyvale, CA). Indigestible NDF was measured as NDF residue after $120 \mathrm{~h}$ of in vitro fermentation (Goering and Van Soest, 1970). Ruminal fluid for the in vitro incubations was collected from 2 nonpregnant dry cows fed only alfalfa hay. Concentrations of all nutrients except for DM were expressed as percentages of DM determined by drying at $105^{\circ} \mathrm{C}$ in a forced-air oven for $>8 \mathrm{~h}$.

Milk samples were analyzed for fat, true protein, and lactose by midinfrared spectroscopy (AOAC, 1990) by Michigan DHIA (East Lansing, MI) and FCM (3.5\%) and solids-corrected milk yield was calculated (Tyrrell and Reid, 1965). Milk samples used for analysis of fatty acid profile were composited based on milk fat yield and centrifuged at $17,800 \times g$ for $30 \mathrm{~min}$ at $8^{\circ} \mathrm{C}$. Fat cake (300 to $400 \mathrm{mg}$ ) was extracted according to Hara and Radin (1978), and methyl esters were formed according to Christie (1982) as modified by Chouinard et al. (1999). Diet ingredients were also analyzed for fatty acid profile; acid-catalyzed methylation and extraction were carried out according to Palmquist and Jenkins (2003) using $\mathrm{C}_{19: 0}$ as the internal standard. Fatty acids were quantified by gas chromatography (model 8500; Perkins-Elmer Corp, Norwalk, CT) according to Kramer et al. (1997) using a SP-2560 capillary column (100 m $\times 0.20 \mathrm{~mm}$ id with $0.02-\mu \mathrm{m}$ film thickness; $\mathrm{Su}-$ pelco, Bellefonte, PA). Oven temperature was $70^{\circ} \mathrm{C}$ for $4 \mathrm{~min}$, then increased $13^{\circ} \mathrm{C} / \mathrm{min}$ to $175^{\circ} \mathrm{C}$ and held for $27 \mathrm{~min}$ before being increased again at $4^{\circ} \mathrm{C} / \mathrm{min}$ to $215^{\circ} \mathrm{C}$ and held for $31 \mathrm{~min}$. Helium flow was $20 \mathrm{~cm} / \mathrm{s}$, and the total run time was $80 \mathrm{~min}$.

Plasma samples were composited to one sample per cow per period for each type of anticoagulant and were analyzed in duplicate to determine concentrations of metabolites and hormones. Glucose was determined essentially as described by Raabo and Terkildsen (1960) using a commercial kit (kit \#510; Sigma Chemical Co.). Determination of NEFA was by an enzymatic method (NEFA C-kit; Wako Chemicals USA, Richmond, VA) as modified (McCutcheon and Bauman, 1986). Plasma BHBA was determined as described (McMurray et al., 1984) using a commercial kit (procedure \#2440; Stanbio Laboratory, Boerne, TX), while true triglyceride was quantified (kit TR0100; Sigma Chemical Co.) according to McGowen et al. (1983). Radioimmunoassay techniques were used for determination of insulin (Coat-ACount; Diagnostic Products Corporation, Los Angeles, CA) and glucagon (Glucagon kit \#GL-32K; Linco Research Inc., St. Charles, MO).

Data were analyzed using the fit model procedure of JMP (version 5.0; SAS Institute, Cary, NC) using the REML method according to the following model:

$$
\mathrm{Y}_{\mathrm{ijk}}=\mu+\mathrm{P}_{\mathrm{i}}+\mathrm{T}_{\mathrm{j}}+\mathrm{C}_{\mathrm{k}}+\mathrm{PT}_{\mathrm{ij}}+\mathrm{e}_{\mathrm{ijk}}
$$

where $\mu$ = overall mean, $\mathrm{P}_{\mathrm{i}}=$ fixed effect of period ( $\mathrm{i}=$ 1 to 2$), T_{j}=$ fixed effect of treatment ( $\mathrm{j}=1$ to 2$), \mathrm{C}_{\mathrm{k}}=$ random effect of cow ( $\mathrm{k}=1$ to 32$), \mathrm{PT}_{\mathrm{ij}}=$ interaction of period and treatment, and $\mathrm{e}_{\mathrm{ijk}}=$ residual. Residual distributions were visually checked for normality. Treatment effects were declared significant at $P<0.05$ and their interactions at $P<0.10$. Tendencies for treatment effects were declared at $P<0.10$. There were no significant period by treatment interactions for variables of interest (all $P>0.10$ ).

Possible causes of variation in response to treatments were of interest in this study. To quantify the effects of increasing dietary starch fermentability, values were calculated by the following formula: Difference $=$ value during HM treatment - value during DG treatment. When period was an important factor $(P<0.25)$ in the variable being considered, the parameter estimate for the period term was added to the difference variable for all cows in one sequence and subtracted from all cows in the other sequence so that both treatment sequences had the same mean. For each regression analysis, the distribution of Cook's D statistic was visually checked and outliers were removed from the analysis. No more than 2 data points were removed from any regression, and quadratic terms were tested for each relationship. 
Table 3. Effects of corn grain conservation method on blood plasma metabolites and hormones.

\begin{tabular}{lcclc}
\hline Item & $\mathrm{DG}^{1}$ & $\mathrm{HM}^{2}$ & $\mathrm{SEM}$ & $P$ \\
\hline Glucose $(\mathrm{mg} / \mathrm{dL})$ & 58.7 & 60.6 & 0.6 & $<0.01$ \\
NEFA $(\mu \mathrm{Eq} / \mathrm{L})$ & 45.5 & 54.1 & 2.1 & $<0.001$ \\
Triglyceride $(\mathrm{mg} / \mathrm{dL})$ & 2.9 & 3.3 & 0.1 & 0.02 \\
BHBA $(\mathrm{mg} / \mathrm{dL})$ & 7.6 & 7.8 & 0.3 & 0.58 \\
Insulin $(\mu \mathrm{IU} / \mathrm{mL})$ & 9.5 & 10.5 & 0.8 & 0.39 \\
Glucagon $(\mathrm{pg} / \mathrm{mL})$ & 189 & 185 & 9 & 0.55 \\
\hline
\end{tabular}

${ }^{1} \mathrm{DG}=$ Dry ground corn diet.

${ }^{2} \mathrm{HM}=$ High moisture corn diet.

\section{RESULTS AND DISCUSSION}

\section{Plasma Metabolites and Hormones}

The HM treatment significantly increased plasma glucose concentration $(P<0.01$, Table 3$)$. Plasma NEFA $(P<0.001)$ and triglyceride $(P=0.02)$ concentrations were also increased by HM, despite the fact that plasma insulin concentration was not significantly altered by treatment $(P=0.39)$. The reason for this unusual result is not obvious. Plasma BHBA $(P=0.58)$ and glucagon $(P=0.55)$ concentrations were not different between treatments.

While dietary treatments altered plasma glucose concentration, there was no evidence of any effect on milk synthesis; yields of milk and milk lactose were not altered by treatment (Table $4 ; P \geq 0.57$ ). Furthermore, plasma glucose concentration was not related to milk yield of cows across periods (Figure 1). The disconnect between plasma glucose concentration and milk lactose yield may be caused by regulation of mammary blood flow, as demonstrated by Cant et al. (2002). Although glucose availability did not seem to limit milk production in this study, it is more likely to be a limiting substrate in early lactation or when a less digestible diet is fed (Rigout et al., 2003).

Table 4. Effects of corn grain conservation method on milk and milk component yields.

\begin{tabular}{lccll}
\hline Item & $\mathrm{DG}^{1}$ & $\mathrm{HM}^{2}$ & $\mathrm{SEM}$ & $P$ \\
\hline Yield (kg/d) & & & & \\
Milk & 38.5 & 38.3 & 1.5 & 0.57 \\
3.5\% FCM & 38.3 & 36.5 & 1.7 & 0.17 \\
Solids-corrected milk & 35.0 & 33.9 & 1.6 & 0.45 \\
Milk fat & 1.34 & 1.24 & 0.08 & 0.15 \\
Milk protein & 1.19 & 1.20 & 0.05 & 0.94 \\
Milk lactose & 1.80 & 1.82 & 0.08 & 0.78 \\
Milk composition (\%) & & & & \\
Milk fat & 3.50 & 3.20 & 0.15 & 0.06 \\
Milk protein & 3.14 & 3.14 & 0.07 & 0.93 \\
Milk lactose & 4.67 & 4.71 & 0.09 & 0.70 \\
\hline
\end{tabular}

${ }^{1} \mathrm{DG}=$ Dry ground corn diet.

${ }^{2} \mathrm{HM}=$ High moisture corn diet.

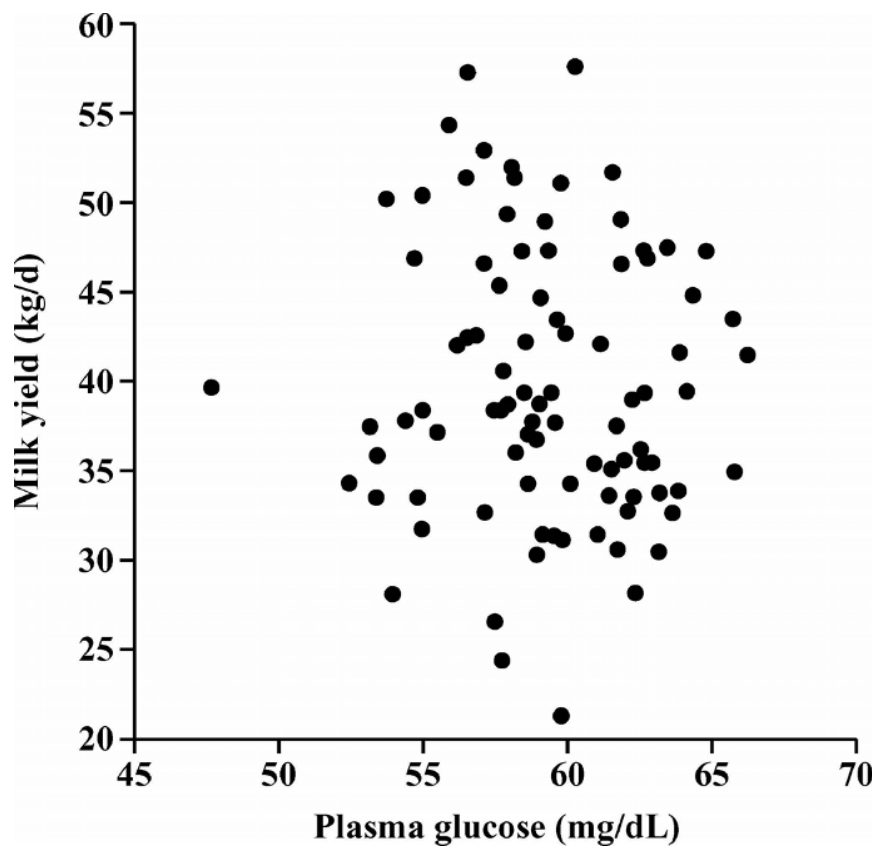

Figure 1. Relationship between plasma glucose concentration and milk yield $(\mathrm{n}=91) . \mathrm{R}^{2}<0.01 ; P=0.61$.

\section{Milk and Milk Component Yield}

Yield of milk and milk components were not consistently altered by treatment (Table 4), although there was a tendency for HM to decrease milk fat concentration $(P=0.06)$. Milk fatty acid profile was altered by treatment (Table 5); concentration of medium-chain fatty acids $\left(\mathrm{C}_{10}\right.$ to $\left.\mathrm{C}_{14}\right)$ in milk decreased with $\mathrm{HM}(P=$ $0.04), \mathrm{C}_{16}$ concentration tended to increase $(P=0.08)$, while long-chain fatty acid concentration was unchanged $(P=0.61)$. The HM treatment increased production of trans-10 $\mathrm{C}_{18: 1}(P=0.01)$, cis- -9 , trans- $11 \mathrm{C}_{18: 2}$ $(P<0.01)$, and total concentration of unsaturated fatty acids $(<0.01)$. These results suggest that ruminal biohydrogenation was less extensive with HM than with DG. Interestingly, $\Delta^{9}$-desaturase activity might have been enhanced by $\mathrm{HM}$, because the ratio of cis- $9 \mathrm{C}_{14: 1}$ to $\mathrm{C}_{14: 0}$ was increased by HM $(P<0.001)$. The $\mathrm{C}_{14: 1}$ to $\mathrm{C}_{14: 0}$ ratio is considered an index of $\Delta^{9}$-desaturase activity because milk $\mathrm{C}_{14}$ is derived almost exclusively from de novo synthesis in the mammary gland (Griinari et al., 2000).

The tendency for a treatment effect on milk fat concentration is explained by the fact that dietary treatments had differential effects on milk fat concentration of high- and low-producing cows (Figure 2). While highproducing cows maintained a relatively consistent milk fat concentration on both diets, lower-producing cows had MFD when fed the HM diet $(\mathrm{R}=0.57, P=0.001$ for preliminary period FCM yield). Other measures of 
Table 5. Effects of corn grain conservation method on milk fatty acid profile.

\begin{tabular}{|c|c|c|c|c|}
\hline Fatty acid (FA) & $\mathrm{DG}^{1}$ & $\mathrm{HM}^{2}$ & SEM & $P$ \\
\hline & \multicolumn{4}{|c|}{ - $(\mathrm{g} / 100 \mathrm{~g}$ of FA) - } \\
\hline $4: 0$ & 4.65 & 4.30 & 0.20 & 0.22 \\
\hline $6: 0$ & 2.45 & 2.13 & 0.11 & 0.04 \\
\hline 8:0 & 1.63 & 1.41 & 0.06 & 0.01 \\
\hline 10:0 & 4.19 & 3.69 & 0.15 & $<0.01$ \\
\hline $12: 0^{3}$ & 5.07 & 4.65 & 0.16 & $<0.01$ \\
\hline $14: 0^{4}$ & 13.5 & 13.0 & 0.2 & 0.05 \\
\hline $14: 1, c i s-9$ & 1.43 & 1.75 & 0.09 & $<0.001$ \\
\hline $15: 0$ & 1.45 & 1.74 & 0.08 & 0.001 \\
\hline $16: 0$ & 31.7 & 31.9 & 0.6 & 0.53 \\
\hline $16: 1$, cis -9 & 2.05 & 2.64 & 0.11 & $<0.001$ \\
\hline $18: 0$ & 6.65 & 5.61 & 0.21 & $<0.001$ \\
\hline $18: 1$, trans $-6,7,8^{5}$ & 0.23 & 0.34 & 0.02 & $<0.001$ \\
\hline $18: 1$, trans -9 & 0.17 & 0.26 & 0.02 & $<0.001$ \\
\hline $18: 1$, trans -10 & 0.47 & 1.48 & 0.28 & $<0.01$ \\
\hline $18: 1$, trans -11 & 0.54 & 0.82 & 0.15 & 0.17 \\
\hline $18: 1$, cis -9 & 15.6 & 15.4 & 0.4 & 0.32 \\
\hline $18: 2$, cis -9, cis -12 & 2.53 & 2.36 & 0.07 & $<0.01$ \\
\hline $18: 2$, cis -9, trans -11 & 0.38 & 0.45 & 0.03 & $<0.01$ \\
\hline $18: 2$, trans -10, cis -12 & 0.010 & 0.015 & 0.002 & 0.18 \\
\hline $18: 3$, cis -9, cis -12, cis -15 & 0.37 & 0.36 & 0.01 & 0.14 \\
\hline $20: 0$ & 0.08 & 0.08 & 0.01 & 0.30 \\
\hline \multicolumn{5}{|l|}{ Total } \\
\hline Short chain $\left(\mathrm{C}_{4}-\mathrm{C}_{8}\right)$ & 8.84 & 8.20 & 0.34 & 0.18 \\
\hline Medium chain $\left(\mathrm{C}_{10}-\mathrm{C}_{14}\right)$ & 24.4 & 23.5 & 0.3 & 0.04 \\
\hline $\mathrm{C}_{16}$ & 34.1 & 34.8 & 0.3 & 0.08 \\
\hline Long chain $\left(>\mathrm{C}_{16}\right)$ & 28.9 & 28.6 & 0.4 & 0.61 \\
\hline Unsaturated & 26.1 & 28.2 & 0.8 & $<0.01$ \\
\hline
\end{tabular}

${ }^{1} \mathrm{DG}=$ Dry ground corn diet.

${ }^{2} \mathrm{HM}=$ High moisture corn diet.

${ }^{3}$ May include $c i s-\mathrm{C}_{11: 1}$

${ }^{4}$ May include $c i s-\mathrm{C}_{13: 1}$

${ }^{5}$ These trans $-\mathrm{C}_{18: 1}$ isomers were not separated.

productive capacity were also related to difference in milk fat concentration: preliminary period values for fluid milk yield, milk lactose yield, milk fat yield, milk protein yield, and solids-corrected milk yield were positively related (all $P<0.01$ ), and DIM was negatively related $(P<0.001)$ to difference in milk fat concentration. However, FCM yield was the only factor retained in a backward stepwise regression model. Preliminary period measures of plasma glucose, NEFA, insulin, glucagon, and leptin concentrations were not correlated with differences in milk fat concentration, nor were initial BCS or BW (all $P>0.10$ ). The observed relationship between production level and MFD response is not in agreement with the results of a study by Gaynor et al. (1995), who found no difference in mean FCM yield of cows that were MFD responders and nonresponders to a low fiber diet. However, the $29-\mathrm{kg} / \mathrm{d}$ range of FCM yields in this regression analysis provides more power than the previous comparison of responders and nonresponders with a range of approximately $14 \mathrm{~kg} / \mathrm{d}$ [SEM = $0.5 ; \mathrm{n}=22$ (Gaynor et al., 1995)].

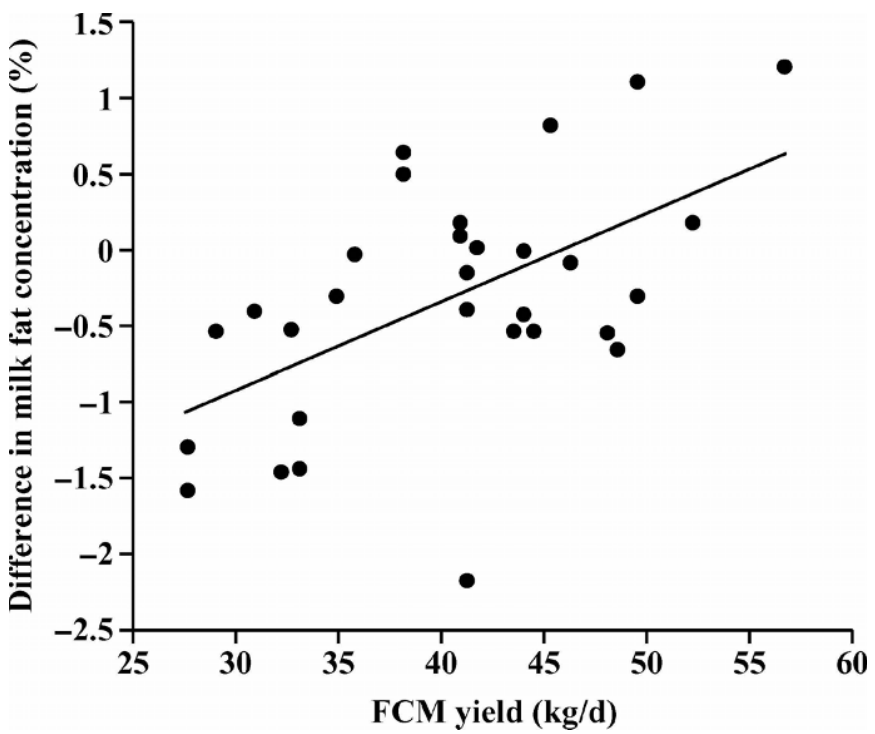

Figure 2. Relationship between preliminary period 3.5\% FCM yield and difference in milk fat concentration $(n=30)$. Difference in milk fat concentration is calculated as milk fat concentration during high moisture corn grain treatment minus milk fat concentration during dry ground corn grain treatment, adjusted for the effect of period $\left(\mathrm{R}^{2}=0.32 ; P=0.001\right)$. Preliminary period fluid milk yield was positively related to difference in milk fat concentration $\left(R^{2}=0.25\right.$; $P<0.01)$.

Milk fat depression is a complicated syndrome, and its cause continues to be a matter of debate. However, 3 hypotheses enjoy the greatest support today (Bauman and Griinari, 2003). The insulin hypothesis suggests that increased insulin concentrations direct fatty acids toward deposition in adipose tissue, limiting their availability in the mammary gland. A second hypothesis points to suppression of ruminal acetate and butyrate production in low fiber or high fat diets, leading to a lack of substrate for de novo fatty acid synthesis in the mammary gland. Finally, the trans fatty acid hypothesis proposes that specific fatty acids produced in the rumen inhibit gene expression of enzymes involved in mammary de novo fatty acid synthesis. None of these hypotheses explicitly propose a mechanism by which MFD should occur only in lower-producing cows.

The data in this study does not support the insulin hypothesis. Although plasma insulin concentrations were numerically higher with HM, both plasma NEFA and triglyceride concentrations were significantly increased. There was no treatment effect on concentration of milk long-chain fatty acids $\left(>\mathrm{C}_{16}\right.$; Table 5$)$, the primary fatty acids derived from plasma NEFA (Griinari et al., 1997). Furthermore, differences in NEFA concentration were negatively related to differences in milk fat concentration ( $\mathrm{R}=-0.48 ; P<0.01)$. It is possible that plasma NEFA did not significantly contribute to 
milk fatty acids for either treatment. According to Emery and Herdt (1991), there is little net mammary uptake of plasma NEFA when concentrations are less than $300 \mu \mathrm{mol} / \mathrm{L}$, and none of the plasma samples analyzed in this study approached that concentration.

Production and mammary supply of acetate and butyrate were not measured in this experiment. In an experiment in which similar diets were fed, Oba and Allen (2003a) calculated that the diet including HM produced an estimated $34 \%$ more acetate and $35 \%$ more butyrate than the diet including DG, yet the HM diet significantly depressed milk fat yield $(P<0.05)$. In another study, infusion of glucose into the external iliac artery caused a $22 \%$ decrease in acetate uptake by the mammary gland without significant depression of milk fat yield (Cant et al., 2002), although glucose uptake was enhanced, possibly providing an alternative substrate for de novo fatty acid synthesis. These findings suggest that acetate supply was likely not the limiting factor in milk fat synthesis for HM. Changes to the rumen environment probably have simultaneous effects on both acetate production and fatty acid biohydrogenation in some cases, which could explain the extensive amount of correlational data linking molar proportions of acetate in the rumen with milk fat concentrations (Emery, 1988).

Although our dietary treatments did not include supplemental polyunsaturated fatty acids, we considered

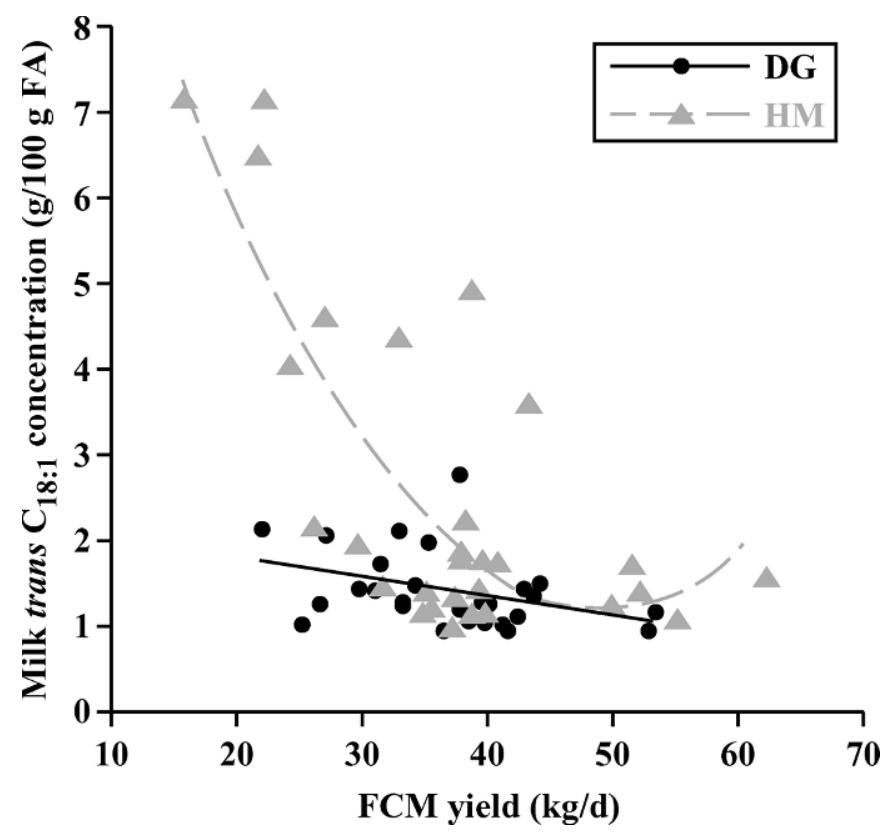

Figure 3. Relationship between 3.5\% FCM yield and milk trans $\mathrm{C}_{18: 1}$ fatty acid concentration. $\Delta=$ high moisture corn diet, - - - quadratic regression $\left(\mathrm{R}^{2}=0.63 ; P<0.001\right) .0=$ Dry ground corn diet, linear regression $\left(\mathrm{R}^{2}=0.15 ; P=0.03\right)$. FA $=$ Fatty acid.

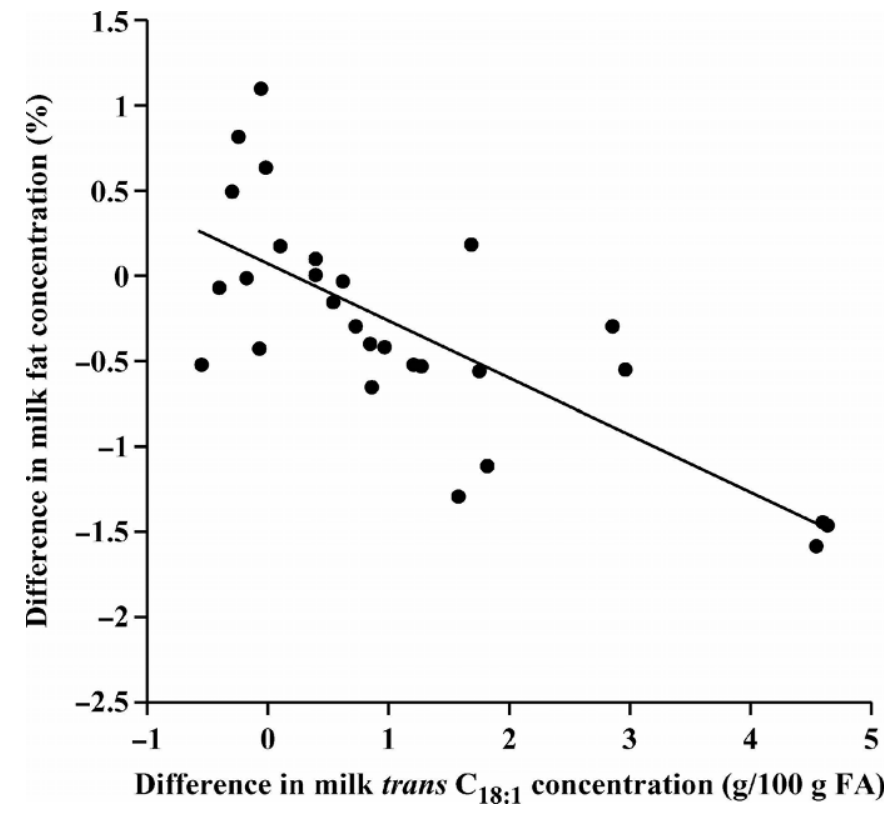

Figure 4. Relationship between difference in milk trans $\mathrm{C}_{18: 1}$ fatty acid concentration and difference in milk fat concentration. Differences are calculated as the value during high moisture corn grain treatment minus the value during the dry ground corn grain treatment, adjusted for the effect of period $\left(\mathrm{R}^{2}=0.56 ; P<0.001\right)$. FA = Fatty acid.

the effects of unsaturated fatty acids on milk fat concentration in this experiment. The concentration of milk trans $\mathrm{C}_{18: 1}$ fatty acids was highly related to FCM yield for HM (Figure 3). High-producing cows showed little change in trans $\mathrm{C}_{18: 1}$ concentration between the dietary treatments, but cows at lower production levels had increases in trans $\mathrm{C}_{18: 1}$ concentration of up to 4 -fold when fed HM. Treatment differences in trans $\mathrm{C}_{18: 1}$ concentration were highly correlated with differences in milk fat percentage (Figure 4), suggesting that one or more specific fatty acids were responsible for the MFD observed in low-producing cows.

Many studies have demonstrated relationships between concentrations of milk trans $\mathrm{C}_{18: 1}$ fatty acids and milk fat concentration (Bauman and Griinari, 2003) and abomasal infusions of trans fatty acids have consistently caused MFD (Gaynor et al., 1994; Gaynor et al., 1996). More recently, it was demonstrated that MFD was highly correlated with increases in trans-10 $\mathrm{C}_{18: 1}$ concentration (Griinari et al., 1998). However, only trans-10, cis-12 $\mathrm{C}_{18: 2}$ has been infused as a pure isomer and shown to cause MFD (Baumgard et al., 2000). The results of this study, interpreted independently, did not identify any specific fatty acid as the likely cause of MFD (Table 6). Surprisingly, changes in trans-10, cis$12 \mathrm{C}_{18: 2}$ concentration were not significantly related to changes in milk fat concentration, although changes in 
Table 6. Pearson correlation coefficients for milk fat concentration and milk fatty acid concentrations.

\begin{tabular}{llc}
\hline Fatty acid & $\mathrm{R}$ & $P$ \\
\hline Total trans $\mathrm{C}_{18: 1}$ & -0.75 & $<0.001$ \\
$18: 1$, trans $-6,7,8^{1}$ & -0.57 & $<0.001$ \\
$18: 1$, trans -9 & -0.60 & $<0.001$ \\
$18: 1$, trans-10 & -0.61 & $<0.001$ \\
$18: 1$, trans- 11 & -0.32 & 0.001 \\
$18: 2$, cis- 9, trans- 11 & -0.61 & $<0.001$ \\
$18: 2$, trans-10, cis-12 & -0.11 & 0.40 \\
\hline
\end{tabular}

${ }^{1}$ These trans- $\mathrm{C}_{18: 1}$ isomers were not separated.

trans-10 $\mathrm{C}_{18: 1}$ concentration were $(P<0.001)$. Our data indicate that trans-10, cis-12 $\mathrm{C}_{18: 2}$ is likely not the only fatty acid capable of suppressing mammary fatty acid synthesis. However, the results are consistent with the hypothesis that trans-10 $\mathrm{C}_{18: 1}$ can cause MFD.

The data obtained in this study do not allow for a definitive conclusion regarding the cause of increased milk trans $\mathrm{C}_{18: 1}$ concentrations in lower-producing cows fed a more fermentable diet. Increased rates of passage might decrease the extent of ruminal biohydrogenation (Dewhurst et al., 2003) and in so doing preserve more biohydrogenation intermediates such as trans $\mathrm{C}_{18: 1}$. However, the data presented here indicate that passage rate may not be a primary factor determining trans fatty acid concentration in milk. Passage rate is generally assumed to increase with feed intake as milk yield increases (NRC, 2001), yet increasing dietary starch fermentability increased milk trans $\mathrm{C}_{18: 1}$ concentrations only in lower-producing cows, presumably those with lower passage rates. Alternatively, it may be that biohydrogenation differences between cows of different production levels are caused by differences in rumen ecology. One bacterial species that is a known biohydrogenator, Butyrivibrio fibrisolvens, was eliminated from the rumen of grass-fed steers when they were switched to a $75 \%$ barley diet and rumen $\mathrm{pH}$ declined (Klieve et al., 2003). Kalscheur et al. (1997) also demonstrated a decrease in ruminal biohydrogenation when feeding a low fiber diet that depressed ruminal $\mathrm{pH}$. Although $\mathrm{pH}$ was not measured in this study, Voelker and Allen (2003a) reported that ruminal $\mathrm{pH}$ was positively correlated with FCM yield $(R=0.43)$, possibly because of higher rates of volatile fatty acid absorption and passage in higher-producing cows (Voelker and Allen, $2003 \mathrm{~b}$ ). If higher-producing cows maintain a more consistent and higher ruminal $\mathrm{pH}$ when fed a highly fermentable diet, they may also maintain a normal biohydrogenation rate.

Based on correlational evidence, production of trans $\mathrm{C}_{18: 1}$ fatty acids appears to have been the dominant factor causing MFD in lower-producing cows fed the HM diet. The novel observation of selective MFD in lower-producing cows demonstrates the need for further investigation of the complex interactions between physiological state, rumen ecology, and nutrition in dairy cattle.

\section{CONCLUSIONS}

Increasing the fermentability of starch in a high concentrate dairy ration increased plasma glucose and NEFA concentrations, despite the lack of significant changes in plasma insulin and glucagon concentrations. Higher starch fermentability caused milk fat depression in low-producing cows but not in more productive cows. This depression was highly correlated with an increase in trans $\mathrm{C}_{18: 1}$ fatty acid concentration in milk of lower-producing cows.

\section{ACKNOWLEDGMENTS}

The authors thank R. E. Kreft, R. A. Longuski, D. G. Main, Y. Ying, C. S. Mooney, J. A. Voelker, K. J. Harvatine, and C. C. Taylor for their technical assistance and West Central Soy for donation of SoyPlus protein supplement.

\section{REFERENCES}

Allen, M. S. 2000. Effects of diet on short-term regulation of feed intake by lactating dairy cattle. J. Dairy Sci. 83:1598-1624.

Association of Analytical Chemists. 1990. Official Methods of Analysis. Vol. 2. 15th ed. AOAC, Arlington, VA.

Bauman, D. E., and J. M. Griinari. 2003. Nutritional regulation of milk fat synthesis. Annu. Rev. Nutr. 23:203-227.

Baumgard, L. H., B. A. Corl, D. A. Dwyer, A. Saebo, and D. E. Bauman. 2000. Identification of the conjugated linoleic acid isomer that inhibits milk fat synthesis. Am. J. Physiol. 278:R179-R184.

Cant, J. P., D. R. Trout, F. Qiao, and N. G. Purdie. 2002. Milk synthetic response of the bovine mammary gland to an increase in the local concentration of arterial glucose. J. Dairy Sci. 85:494-503.

Chouinard, P. Y., L. Corneau, D. M. Barbano, L. E. Metzger, and D. E. Bauman. 1999. Conjugated linoleic acids alter milk fatty acid composition and inhibit milk fat secretion in dairy cows. J. Nutr. 129:1579-1584.

Christie, W. W. 1982. A simple procedure for rapid transmethylation of glycerolipids and cholesteryl esters. J. Lipid Res. 23:1072-1075.

Dewhurst, R. J., R. T. Evans, N. D. Scollan, J. M. Moorby, R. J. Merry, and R. J. Wilkins. 2003. Comparison of grass and legume silages for milk production. 2. In vivo and in sacco evaluations of rumen function. J. Dairy Sci. 86:2612-2621.

Emery, R. S. 1988. Milk fat depression and the influence of diet on milk composition. Vet. Clin. North Am. Food Anim. Pract. 4:289-305.

Emery, R. S., and T. H. Herdt. 1991. Lipid nutrition. Vet. Clin. North Am. Food Anim. Pract. 7:341-352.

Ensinck, J. W., C. Shepard, R. J. Dudl, and R. H. Williams. 1972. Use of benzamidine as a proteolytic inhibitor in the radioimmunoassay of glucagon in plasma. J. Clin. Endocrinol. Metab. 35:463-467.

Gaynor, P. J., R. A. Erdman, B. B. Teter, A. V. Capuco, and D. R. Waldo. 1996. Glucose and norepinephrine challenges during abomasal infusion of cis or trans octadecenoates in Holstein cows. J. Dairy Sci. 79:1590-1595.

Gaynor, P. J., R. A. Erdman, B. B. Teter, J. Sampugna, A. V. Capuco, D. R. Waldo, and M. Hamosh. 1994. Milk fat yield and composition 
during abomasal infusion of cis or trans octadecenoates in Holstein cows. J. Dairy Sci. 77:157-165.

Gaynor, P. J., D. R. Waldo, A. V. Capuco, R. A. Erdman, L. W. Douglass, and B. B. Teter. 1995. Milk fat depression, the glucogenic theory, and trans-C18:1 fatty acids. J. Dairy Sci. 78:2008-2015.

Goering, H. K., and P. J. Van Soest. 1970. Forage Fiber Analysis (Apparatus, Reagents, Procedures, and Some Applications). Agric. Handbook No. 379. ARS-USDA, Washington, DC.

Griinari, J. M., B. A. Corl, S. H. Lacy, P. Y. Chouinard, K. V. Nurmela, and D. E. Bauman. 2000. Conjugated linoleic acid is synthesized endogenously in lactating dairy cows by $\Delta(9)$-desaturase. J. Nutr. 130:2285-2291.

Griinari, J. M., D. A. Dwyer, M. A. McGuire, D. E. Bauman, D. L. Palmquist, and K. V. Nurmela. 1998. Trans-octadecenoic acids and milk fat depression in lactating dairy cows. J. Dairy Sci. 81:1251-1261

Griinari, J. M., M. A. McGuire, D. A. Dwyer, D. E. Bauman, and D. L. Palmquist. 1997. Role of insulin in the regulation of milk fat synthesis in dairy cows. J. Dairy Sci. 80:1076-1084.

Hach, C. C., B. K. Bowden, A. B. Lopelove, and S. V. Brayton. 1987. More powerful peroxide Kjeldahl digestion method. J. AOAC 70:783-787.

Hara, A., and N. S. Radin. 1978. Lipid extraction of tissues with a low-toxicity solvent. Anal. Biochem. 90:420-426.

Kalscheur, K. F., B. B. Teter, L. S. Piperova, and R. A. Erdman. 1997. Effect of dietary forage concentration and buffer addition on duodenal flow of trans-C18:1 fatty acids and milk fat production in dairy cows. J. Dairy Sci. 80:2104-2114.

Karkalas, J. 1985. An improved enzymatic method for the determination of native and modified starch. J. Sci. Food Agric. 36:10191027.

Klieve, A. V., D. Hennessy, D. Ouwerkerk, R. J. Forster, R. I. Mackie, and G. T. Attwood. 2003. Establishing populations of Megasphaera elsdenii YE 34 and Butyrivibrio fibrisolvens YE 44 in the rumen of cattle fed high grain diets. J. Appl. Microbiol. 95:621-630.

Knowlton, K. F., B. P. Glenn, and R. A. Erdman. 1998. Performance, ruminal fermentation, and site of starch digestion in early lactation cows fed corn grain harvested and processed differently. J. Dairy Sci. 81:1972-1984.

Kramer, J. K., V. Fellner, M. E. Dugan, F. D. Sauer, M. M. Mossoba, and M. P. Yurawecz. 1997. Evaluating acid and base catalysts in the methylation of milk and rumen fatty acids with special emphasis on conjugated dienes and total trans fatty acids. Lipids $32: 1219-1228$

Matsunaga, N., T. Goka, K. T. Nam, S. Oda, A. Ohneda, and Y. Sasaki. 1997. Inhibition of GH releasing factor (GRF)-induced GH secretion by intraruminal infusion of volatile fatty acids (VFA) in sheep. Endocr. J. 44:133-140.

McCutcheon, S. N., and D. E. Bauman. 1986. Effect of chronic growth hormone treatment on responses to epinephrine and thyrotropinreleasing hormone in lactating cows. J. Dairy Sci. 69:44-51.

McGowan, M. W., J. D. Artiss, D. R. Strandbergh, and B. Zak. 1983. A peroxidase-coupled method for the colorimetric determination of serum triglycerides. Clin. Chem. 29:538-542.

McMurray, C. H., W. J. Blanchflower, and D. A. Rice. 1984. Automated kinetic method for D-3-hydroxybutyrate in plasma or serum. Clin. Chem. 30:421-425.

NRC. 2001. Nutritional Requirements of Dairy Cattle. 7th rev. ed. Natl. Acad. Sci., Washington, DC.

Oba, M., and M. S. Allen. 2003a. Effects of corn grain conservation method on feeding behavior and productivity of lactating dairy cows at two dietary starch concentrations. J. Dairy Sci. 86:174-183.

Oba, M., and M. S. Allen. 2003b. Effects of corn grain conservation method on ruminal digestion kinetics for lactating dairy cows at two dietary starch concentrations. J. Dairy Sci. 86:184-194.

Palmquist, D. L., and T. C. Jenkins. 2003. Challenges with fats and fatty acid methods. J. Anim. Sci. 81:3250-3254.

Raabo, E., and T. C. Terkildsen. 1960. On the enzymatic determination of blood glucose. Scand. J. Clin. Lab. Invest. 12:402-407.

Rigout, S., C. Hurtaud, S. Lemosquet, A. Bach, and H. Rulquin. 2003. Lactational effect of propionic acid and duodenal glucose in cows. J. Dairy Sci. 86:243-253.

Tyrrell, H. F., and J. T. Reid. 1965. Prediction of the energy value of cow's milk. J. Dairy Sci. 48:1215-1223.

Van Soest, P. J., J. B. Robertson, and B. A. Lewis. 1991. Methods for dietary fiber, neutral detergent fiber, and nonstarch polysaccharides in relation to animal nutrition. J. Dairy Sci. 74:35833597.

Voelker, J. A., and M. S. Allen. 2003a. Pelleted beet pulp substituted for high-moisture corn: 1 . Effects on feed intake, chewing behavior, and milk production of lactating dairy cows. J. Dairy Sci. 86:3542-3552.

Voelker, J. A., and M. S. Allen. 2003b. Pelleted beet pulp substituted for high-moisture corn: 3. Effects on ruminal fermentation, $\mathrm{pH}$, and microbial protein efficiency in lactating dairy cows. J. Dairy Sci. 86:3562-3570. 